\title{
ETIKA BERMEDIA SOSIAL PEREMPUAN FATAYAT MELALUI PENGUATAN PENGETAHUAN LITERASI MEDIA DI SITUBONDO
}

\author{
Oleh: \\ Nur Ainiyah \\ Universitas Ibrahimy Situbondo \\ nura_ifan@yahoo.com
}

\begin{abstract}
:
Media and technology take us to an era of information literacy. The pattern of communication and conversation on social media recently tends to provoke, shows the low ethics of Indonesian society in in the public domain communication such as social media. It is undeniable that women also took part as a subject in social media, including the Fatayat group in Situbondo. This study emphasizes the empowerment of social media ethics towards fatayat women in Situbondo through media literacy to fight hoax. It was a qualitative-explorative research by examined how fatayat ethics and behavior in communication through social media and how women are ethically empowered through strengthening knowledge media literacy. Social media in fatayat women live brings and forms a new world in interacting and communicating. Manage contents via Facebook shared and published by fatayat members, making them learn literacy. Strengthening social media ethics through media literacy is carried out in various stages, especially through monthly meetings, thematic discussions and the role of women through fatayat
\end{abstract}

Keyword: Perempuan Fatayat, Media Sosial, Etika.

\section{A. Pendahuluan`}

Perkembangan media dan teknologi membawa kita pada satu era melek informasi Pola komunikasi dan percakapan di media sosial akhirakhir ini yang cenderung memprovokasi, menunjukkan rendahnya etika masyarakat Indonesia dalam berkomunikasi di ranah publik seperti media sosial. Literasi media sosial yang rendah perlu diatasi melalui edukasi dan pelatihan sejak dini agar masyarakat tidak mudah diadu domba dengan isu-isu yang tidak bertanggung jawab baik politik, ekonomi, social, budaya dan agama. Sehingga kegaduhan dan sistuasi tidak nyaman bisa dihindari.

Perkembangan media sosial berkembang begitu pesat. Dunia maya dari waktu ke waktu seperti air yang mampu melepaskan dahaga para

$$
\text { JURNAL LISAN AL-HAL } \mid 69
$$


penggunanya. Baik muda sampai tua sekarang sudah menggunakan media sosial untuk berkomunikasi dan mencari Informasi. Apalagi di zaman digital ini, media mempunyai efek luar biasa kuatnya mempengaruhi kehidupan manusia. Sehingga kehidupan sekarang bisa dianggap manusia tiada hari tanpa bermedia. Dengan perkembangan teknologi saat ini media mengembangkan perannya tidak hanya sebagai sarana komunikasi tapi juga sebagai sarana untuk mendapatkan dan mengedarkan Informasi.

Perkembangan-perkembangan tersebut membuat semua orang bisa berbagi informasi dengan mudah dan cepat. Efek negatifnya orang dengan gampangnya membuat berita dan mengedarkan tanpa bisa diketahui kebenaran dari berita tersebut. Berita yang tanpa diketahui akan kebenarannya itu disebut dengan Hoax. Istilah hoax jika ditelusuri memang segelap artinya. Hoax memiliki akar yang panjang seiring dengan cakupan akibatnya yang cukup buruk pada publik luas. Isu-isu yang laris manis dan konsisten menjadi perdebatan, di antaranya, isu jati diri Presiden Jokowi, isu tenaga kerja asing China menyerbu Indonesia, isu bangkitnya komunisme, isu kebhinekaan, isu penguasaan Indonesia oleh asing. Isu ummat Islam didzholimi, dan lainnya. Isu-isu ini diolah menjadi hoax dan disebarluaskan oleh media abal-abal melalui media sosial. Celakanya, orang yang membacanya mudah tersulut, terprovokasi tanpa cek dan ricek kebenaran berita atau informasinya lagi langsung turut memviralkan dengan repost, reshare, dan posting up-date status.

Ketidak hati-hatian nitizen atau pengguna media sosial disadari atau tidak akan memberi efek positif dan negatif tergantung substansi content media yang disebarluaskan. Menyebarnya berita yang menyentuh dan menggugah sisi emosionalitas perempuan, disadari atau tidak akan memudahkan perempuan untuk berempati bahkan menaggapi serasa serius berita yang "emosional dan menyentuh". Sehingga tidak disadari akan segera menekan "LIKE" atau "SHARE" sebagai sikap peduli atas berita tertentu.

Baru-baru ini perempuan juga menjadi "yang dikorbankan" dalam rumor pemberitaan penculikan anak yang berkembang di media sosial facebook dan WA, sehingga beberapa perempuan yang sedikit "terganggu secara kejiwaan" menjadi tertuduh sebagai pelaku penculikan yang pada akhirnya tidak membuktikan apa-apa atau hanya HOAX saja. Menanggapi ini harusnya perempuan menjadi lebih cerdas dalam menganalisis kontent media sehingga tidak mudah dipengaruhi oleh pemberitaan palsu.

Popularitas media sosial tidak terlepas dari sifat media baru yang tidak terikat pada keredaksian sepeti pada media arus utama. Ketika media mainstremaing terikat dengan sistem editorial yang kaku, yang 
membutuhkan waktu dan personel yang banyak. Media sosial memangkasnya. Dengan media sosial apapun bisa dipublikasikan dan siapa pun bisa mempublikasikannya saai itu juga.

Kebutuhan akan keinginan perempuan untuk menegaskan eksistensi diri ini kemudian bisa dilakukan sangat mudah dengan melakukan publikasi berbagai kegiatan yang melalui media sosial facebook dan whatsapp. Kebutuhan dan keinginan untuk selalu eksis ini terkadang membawa perempuan pada posisi yang tidak seharusnya. Terkadang keinginan untuk menampilkan kesan baik, pintar dan terpelajar malah gagal ketika perempuan tidak bisa mengemas content media baik itu gambar maupun pesan tertulis di media sosial. Konfik pribadi, golongan bahkan konflik politik menjadi bagian dari isi pemberitaan terkadang menjebak perempuan untuk merespon agar nampak "tidak ketinggalan berita" malah membawa perempuan pada arus konflik dalam media sosial.

Perempuan Fatayat merupakan perempuan yang dicitrakan sebagai perepuan yang religius dan sentitif terhadap persoalan sosial kemasyarakatan, tak jarang para prempuan ini juga ditokohkan sehingga mereka memiliki peranan dan posisi strategis ditengah tengah lingkungan sosialnya. Atas sekian citra bagi perempuan fatayat inilah, pada akhirnya mereka membuat berbagai pilihan media komunikasi yang dirasa efektif dan memudahkan. Akan tetapi persoalan muncul ketika para perempuan fatayat tidak mengetahui etika bermedia sosial, ketidaktahuan ini tentu bisa berefek negatif terhadap peran sosial perempuan. Misalkan tanpa mereka sadari menulis pengalaman pribadi yang bernuasa "hated speech" atau merespon informasi provokatif bahkan menyebarkan berita "hoax". Tentu hal ini sangat ironis ketika perempuan fatayat yang dicitrakan religius ikut terjebak dalam simpang siur berita dan informasi melalui media sosial yang "keliru".

Perempuan Fatayat Situbondo sebagai organissasi sosial keagamaan yang bergerak untuk pemberdayaan perempuan sudah seharusnya merespon hal-hal yang baik dan brmanfaat bagi perempuan itu sendiri (kaumnya) dan masyarakat melalui hal-hal baik dan berita baik yang memberdayakan. Organisasi yang merupakan underbown NU cabang situbondo yang selama ini cukup aktif dalam gerakan pemberdayaan sosial keagamaan. Dengan sistem organisasi yang cukup masif mekanistis, organisasi ini bergerak cukup kondusif dan terorganisisr dengan baik dalam interaksi dengan anggota-anggotanya melalui beberapa program kerja, kegiatan dan rapat-rapat koordinasi lainnya. Dua tahun terakhir ini media komunikasi yang menjadi pilihan anggota dan pengurus adalah

$$
\begin{array}{l|l}
\text { JURNAL LISAN AL-HAL } & 71
\end{array}
$$


komunikasi di grup media sosial seperti facebook dan whattsap (WA). Hal ini menyesuaikan kebutuhan komunikasi organisasi bagi perempuan Fatayat.

Terkait degan kebutuhan berkomunikasi dengan menggunakan media sosial inilah, akhirnya anggota mulai belajar menggunakan tomboltombol dan fitur-fitur yang muncul di layar smartphone mereka. Keahlian teknis ini tentu cepat dipahami dan dipelajari oleh perempuan, justru persoalan akan muncul ketika perempuan tidak siap dengan terpaan informasi yang beredar di dunia maya melalui media facebook dan grup whattsap. "keawaman" perempuan fatayat akan media, informasi dan teknologi membuat mereka mengalami "media shock attau information shock" . Keterkejutan media dan informasi menyebabkan perempuan menganggap semua berita dan informasi yan muncul di layar telepon mereka adalah berita benar baik itu pesan informatif, provokatif bahkan edukatif. Yang lebih miris lagi ketika berita dan informasi yang provokatif, hate speech (berita kebencian) mengundang perempuan untuk turut "mengumpat", "menghujat" bahkan "membenci". Di sadari atau tidak melalui media sosial menjadikan perempuan sebagai sasaran pemberitaan baik untuk tujuan propaganda, kepentingan, konflik bahkan tujuan pemberdayaan. Lepas dari hal ini perempuan harus memahami literasi media agar bisa menggunkan media sosial dengan bijak dan berdaya. Dan juga bisa merespon content media sosial secara arif dan tidak terburuburu sehingga bisa memilih berita yang benar dan tidak benar.

Atas berbagai pertimbangan riel terhadap fenomena perempuan inilah peneliti prihatin, bagaimana perempuan yang notabene anggota fatayat yang secara moral dan spiritual adalah perempuan yang bisa memberi perubahan dan kontribusi bagi kaum dan masyarakatnya terjebak pada pusaran informasi yang membingungkan, informasi penebar kebencian dan lain-lain. Oleh karena itu peneliti merasa penting untuk mengetahui sejauh mana penggunaan dan pengelollaan peremppuan fatayat dalam menampilkan dan mengolah pesan melalui media sosial. Bagaimana pemahaman mereka mengenai etika berinternet dan mermedia sosial. Dan mereka gunakan untuk media soosial yang mereka lakukan selama ini. Seberapa jauh pengetahuan mereka akn literasi media yang memungkinkan mereka tidak terjebak dalam berita yang tidak jelas, berita palsu dan membingungkan.

\section{B. Metode Penelitian}

Penelitian ini pemberdayaan etika bermedia sosial terhadap perempuan fatayat situbondo melalui literasi media untuk melawan hoax,

$$
72 \text { JURNAL LISAN AL-HAL }
$$


merupakan penelitian kualitatif- eksploratif dengan mencoba menelaah dan mengkaji bagaimana etika dan prilaku perempuan fatayat dalam komunikasi melalui media sosial bagaimana kemudian prempuan diberdayakan secara etika melalui penguatan pengetahuan literasi media agar perempuan tidak terjebak pada informasi yang menyesatkan.

Dengan menggunakan pendekatan kualitatif peneliti akan melakukan prosedur pengumpulan data sebelum melakukan analisa data. Strategi pengumpulan data akan peneliti lakukan dengan teknik; observasi (pengamatan berperan serta), wawancara mendalam, dan pengumpulan data /dokumen tertulis yang relevan dengan penelitian ini, seperti hasilhasil penelitian yang sejenis dengan penelitian ini, gambar, foto maupun data statistic yang dibutuhkan. dengan begitu peneliti bisa melakukan analisa data dengan menggunakan teori-teori yang relevan terkait dengan media sosial, gender dan perempuan.

Untuk subjek penelitian dalam penelitian ini, adalah perempuan anggota Fatayat Cabang Situbondo dengan kategori latar belakang yang berbeda beda sesuai dengan perannya meliputi pengurus harian Fatayat cabang situbondo dan beberapa anggota yang cukup aktif dalam keorganisasian Fatayat, dan anggota yang mengetahui masalah penelitian dan bisa memberikan informasi sebanyak-banyaknya terkait dengan focus penelitian.

Sedangkan untuk obyek penelitian meliputi aspek komunikasi yang menjadi obyek dalam peneltian ini adalah konten-konten verbal dan non verbal dalam komunikasi media sosial perempuan yang mengundang respon positif dan negatif di kalangan perempuan fatayat pengguna media sosial.

Mengenai analisa data, dalam penelitian ini akan dilakukan dengan pendekatan kualitatif. Setelah peneliti mengumpulkan data sekunder dan primer, data sosial dan media sosial terkait penggunaan komunikasi media sosial yang dilakukan perempuan dan berbagai responnya serta pemberdayaan etika media sosial. Maka peneliti akan melakukan pemilahan data dengan reduksi data dan display data. Menurut Miles dan Huberman dalam Moloeng, pada dasarnya analisis data ini didasarkan pada pandangan paradigma positivisme. Analisis data itu dilakukan dengan mendasarkan diri pada penelitian lapangan apakah : satu atau lebih dari satu situs.

Reduksi data penting dilakukan untuk memilah dan mengelompokkan data sesuai dengan domain analisisnya. Dengan begitu peneliti akan melakukan langkah analisa data kualitatif. Dengan begitu peneliti bisa memformulasikanpemberdayaan etika bermedia sosial

$$
\text { JURNAL LISAN AL-HAL } \mid 73
$$


melalui pengetahuan literasi mediauntuk melawan hoax terhadap prempuan fatayat. langkah ini merupakan langkah awal dalam metode analisis induktif untuk mendapatkan kebenaran hasil penelitian.

\section{Hasil Penelitian dan Temuan Penelitian}

\section{Perempuan Fatayat Situbondo dan Media Sosial}

Secara geografis Situbondo merupakan salah satu kabupaten di Jatim yang kental dengan budaya Madura. Dengan tradisi kesantrian dan religiusitas yang sangat kental bisa dirasakan ketika berada di situbondo.

Fatayat Situbondo merupakan organisasi perempuan Nahdatul Ulama, yang menjadi wadah bagi perempuan situbondo dalam berorganisasi, mengasah pengetahuan, skill dan keterampilan. Sebagai ormas yang besar Fatayat selalu dilirik oleh berbagai kelompok kepentingan untuk bisa bekerjasama dalam politik terutama menjelang pemilu legislatif maupun Pilkada. Meskipun Fatayat bukan merupakan organisasi yang bergerak dalam bidang politik akan tetapi dalam iklim perpolitikan Situbondo cukup diperhitungkan kontribusinya.

Organisasi ini cukup masif secara keorganisasian mulai dari tingkat cabang situbondo, 17 anak cabang Kecamatan dan kurang lebih 170 ranting Desa. Kepemimpinan yang berjalam bisa dikatakan cukup professional, di mana semua pimpinan anak cabang dan ranting cukup aktif berkomunikasi dan berkegiatan bersama dalam kehidupan bermasyarakat.

Sebagai badan otonom Nahdlatul Ulama, tentu saja Fatayat NU tidak akan lepas dari tugas-tugas yang disebutkan di atas. Kongres Fatayat NU ke-15 yang dihelat pada 19-22 September 2015 di Surabaya sudah tentu harus mampu memetakan masalah, menjawab tantangan, dan sekaligus menemukan formulasi-formulasi dan startegi-strategi jitu untuk menjawabnya. Keterlibatan Fatayat NU sebagai organisasi perempuan sangat ditunggu untuk memberi kontribusi dalam berbagai bidang oleh masyarakat. Bila menengok sejarah, di tahun 70-80-an, Fatayat dan Muslimat NU telah memainkan peranan yang penting dalam mempengaruhi para Kiai untuk mengkaji ayat-ayat al-Qur'an dan Hadis yang terkait dengan Keluarga Berencana (KB), hingga keluarlah istilah Keluarga Maslahah, dan mendirikan Lembaga Kemaslahatan Keluarga (LKK) yang mendukung program KB. LKK ini disupport juga oleh rumah sakit-rumah sakit dan klinik-klinik. LKK juga mengadakan programprogram pelatihan bagi kesehatan tenaga kerja, baik tenaga kerja domestik maupun luar negeri, menyebarkan pamflet-pamflet dan buku-

74 JURNAL LISAN AL-HAL 
buku tentang kesehatan reproduksi. Rasanya, ini menjadi salah satu success story Fatayat dan Muslimat NU dahulu.

Dalam hal penggunaan media sosial para perempuan yang notabene adalah pengurus fatayat NU cabang Situbondo sama seperti masyarakat di dunia pada umumnya, hampir semua mengenal media sosial. Karena di zaman informasi dan teknologi serta keterbukaan, segala kemudahan berkomunikasi tersedia dalam satu telepon selular. Perempuan bisa mendownload dan menggunakan berbagai aplikasi terkait dengan beberapa kebutuhan. Kebutuhan gaya hidup, kebutuuhan ekonomi, kebutuhan informasi pendidikan, informasi kesehatan, sosial budaya termasuk informasi politik di dalamnya.

Pengurus Fatayat cabang situbondo berjumlah 30 orang dan semua adalah perempuan, hampir semua memiliki akun facebook dan menggunakan whats up termasuk instagram. Media sosial yang favorit menjadi pilihan bagi mereka adalah facebook. Dengan alas an facebook memberi kemudahan dalam menjalin pertemanan dan komunikasi satu sama lainnya.

\section{Temuan Penelitian}

\section{Pemahaman Etika Media Sosial Perempuan}

Media sosial adalah media komunikasi yang mampu menimbulkan keserempakan, dalam arti kata khalayak dalam jumlah yang relatif sangat banyak secara bersama-sama pada saat yang sama memperhatikan pesan yang dikomunikasikan melalui media tersebut, misalnya surat kabar, radio, siaran televisi. Media sosial juga dapat disebut sebagai media online dimana para penggunanya dapat dengan mudah berpartisipasi, berbagi, dan menciptakan isi meliputi blog, sosial network, atau jejaring sosial, wiki, forum dan dunia virtual. Blog dan jejaring sosial mungkin merupakan bentuk media sosial yang paling umum digunakan oleh masyarakat saat ini.

Keberadaan media sosial sangat berpengaruh dalam kehidupan. Selain dampak positif, dampak negatif yang ditimbulkan dari media sosial juga beragam. Berbagai macam modus kejahatan di medis sosial banyak ditemukan terutama pada perempuan fatayat seperti kekerasan, pelecehan, bahkan tindak kriminal seperti penipuan, pemerasan, pemerkosaan, dan sebagainya.

Mengingat pengaruh negatif media sosial terhadap perempuan fatayat yang sangat banyak dan meresahkan, perlu dilakukan arahan, tuntunan, bimbingan, panduan, dan pengawalan dari pihak-pihak seperti orangtua, guru, dan pemangku kepentingan dalam pendidikan anak dan

$$
\text { JURNAL LISAN AL-HAL } \mid 75
$$


perempuan fatayat. Perkembangan media sosial terasa begitu amat pesat pada kurun waktu terakhir ini. Media ini membantu seseorang untuk bertemu teman lama dan mengenal teman baru. Mendekatkan jarak teman yang berada pada daerah yang berbeda. Salah satu media sosial yang banyak digunakan oleh anak-anak dan perempuan fatayat adalah facebook, twitter, BBM, whats Up dan media sosil lainnya.

Media Sosial adalah salah satu anak dari duniamaya yang saat ini telah menjadi sebuah trend yang memiliki dampak yang begitu kuat terhadap perkembangan pola fikir manusia. Sebagian besar penduduk dunia telah menjadikan media sosial sebagai salah satu kebutuhan hidup yang boleh dikatakan primer, tercatat saat ini di Indonesia pengguna media sosial mencapai kurang lebih 62.56 juta orang, 43.06 juta pengguna Facebook dan 19.5orang pengguna Twitter (sumber:menkoinfo), dan itu dinyatakan sebagai pengguna aktif, danpengguna aktif tersebut di dominasi oleh kalangan perempuan fatayat .Masa perempuan fatayat adalah masa yang memiliki ke pekaan yang begitu kuat terhadap halhalyang baru, sehingga perempuan fatayat sangat begitu mudahnya beradaptasi terhadap sesuatu yang barutersebut, apalagi media sosial adalah media yang begitu banyak menawarkan fitur-fitur yangmengasyikkan, sehingga para perempuan fatayat dengan sangat mudah tergiur oleh fitur-fitur yangmengasyikkan tersebut tanpa mempedulikan konten-konten yang terkandung dalam fitur-fiturtersebut positif atau negatif, hal ini sebenarnya menjadi sebuah ujian bagi para perempuan fatayat bagaimana mereka bisa mengawas diri untuk bertindak sebagaimana etika yang berlaku, namun hal tersebut rupanya tidak sebanding dengan nilai-nilai hedonis yang ditawarkanmedia sosial tersebut, media sosial disuatu sisi memberikan manfaat positif bagi mobilitaskebutuhan manusia namun di sisi lain juga telah membawa dampak negatif bagiperkembangan pola fikir manusia terutama kalangan perempuan fatayat .Telah banyak kita lihat berita-berita di media massa yang memuat tentang dampak yang ditimbulkan dari media sosial, mulai dari berita kesuksesan yang didapatkan darimemanfaatkan media sosial sampai berita tentang penculikan, prostitusi dll sebagainya,semua itu hanyalah sebagian kecil saja, dampak-dampak tersebut telah memberi semacam sugesti terhadap masyarakat untuk bagaimana lebih bijak dalam memanfaatkan media social tersebut terutama para perempuan fatayat, namun hal tersebut tidak begitu berpengaruh dari sebagian besar perempuan fatayat yang bergelut dengan media sosial, bagi kalangan perempuan fatayat media sosial adalah dunia ke dua bagi mereka, terutama pada jejaring sosial setenar facebook dan twitter, tentunya 
media sosial menawarkan kepada perempuan fatayat bagaiman berinteraksi, berkomunikasi, dan bersosialisasi dengan cara yang mudah dan baru, dan hal itu telah mengubah sebagian besarpola fikir perempuan fatayat dalam bergaul dalam kehidupan sehari-hari, sehingga tanpa kita sadari bahwasanya media sosial telah menjadi semacak konstruksi sosial dalam masyarakat moderen.

\section{a. Perempuan Fatayat sebagai pengguna media sosial cerdas}

Kemajuan teknologi dengan kehidupan manusia seakan-akan tidak dapat dipisahkan. Kemajuan teknologi tentunya menyebabkan perubahan yang begitu besar terhadap kehidupan umat manusia di berbagai bidang dan memberikan dampak yang begitu besar terhadap nilai-nilai kebudayaan yang dianut masyarakat, termasuk gaya hidup dan pola pikir masyarakat.

Termasuk gadget telah dimiliki oleh setiap kalangan, terutama pada para perempuan fatayat. Hal ini dikarenakan bentuk gadget yang beraneka ragam dan sangat menarik serta memiliki berbagai fungsi selain untuk berkomunikasi juga untuk berbagi, mencipta, dan menghibur dengan audio, video, gambar, tulisan, musik dan sebagainya.

Fitur-fitur inilah kemudian yang menjadikan media baru dalam komununikasi perempuan fatayat seolah mengganti komunikasi konvensional tatap muka yang biasa dilakukan. Perempuan fatayat menjadi sangat bergantung pada teknologi smartphone untuk berkomunikasi dengan sesama perempuan fatayat lainnya. Ruang untuk nongkrong dan bercengkarama menjadi lebih modern dan bergaya.

Kecanduan teknologi dalam bidang informasi dan komunikasi memang sangat mudah dilihat, terutama jika kecanduan itu dialami oleh perempuan fatayat .Sebut saja kecanduan internet dalam bidang informasi dan kecanduan pada handphone dalam bidang komunikasi. Kecanduan yang dapat mengubah gaya hidup perempuan fatayat jaman sekarang. Internet merupakan salah satu teknologi yang sering digunakan oleh mereka. Uangkapan informasan Silina:

"Hampir setiap waktu saya menggunakan telepon genggam, mulai dari bangun tidur sampai mau tidur kembali, dan setiap saat selalu membuka facebook, mulai dari menceritakan kegiatan sehari hari yang saya dokumentasi, kegiatan mengajar disekolah, makan-makan, jalan jalan bahkan rapat sekalipun saya masih sempat membuka facebook"1

Yang dialami oleh Sillina, banyak perempuan lain juga mengalami,

${ }^{1}$ Wawancara dengan Sillina, September 2018

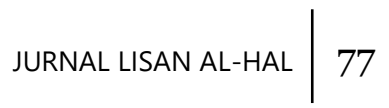


bagaimana ketergantungan akan teknologi dan telepon genggam dalam kehidupan sehari hari. Daya tarik internet dan media sosial inilah yang kemudian memegang peranan penting dalam membangun kemampuan berkomunikasi seseorang. Perempuan fatayat saat ini begitu peka dengan perubahan yang terjadi dalam teknologi sosial, mereka mengikuti perkembangan tersebut dan menguasainya dengan proses belajar menggunakan metode "Trials and Error" (Rasmita Kalasi, 2014).

\section{b. Telepon Selular Bagian dari Gaya Hidup dan Alat Komunikasi Perempuan Fatayat}

Saat ini perkembangan dalam teknologi komunikasi mempunyai pola yang hampir mirip dengan pertumbuhan hidup manusia di dunia ini. Jelasnya, alat komunikasi sangat berkembang pesat sama seperti perkembangan hidup manusia. Pada awalnya manusia pada zaman batu masih lembek melakukan komunikasi jarak jauh secara verbal atau memerlukan waktu lama. Seperti mengirim surat, berteriak, dll. Tetapi cara ini tidak menghasilkan komunikasi yang baik. Ada yang menunggu terlalu lama, dan ada pula yang capek karena berteriak. Maka dari itu, lahirlah seorang penemu yang bernama Alexander Graham Bell. Beliau adalah penemu alat teknologi komunikasi yaitu telepon dan radio pada tahun 1800-an.

Dari tahun ke tahun teknologi komunikasi melaju pesat dengan sangat cepat. Karena dengan bantuan ilmuan-ilmuan ternama yang telah membuat teknologi komunikasi kian canggih. Diciptakanlah telepon tanpa kabel, atau biasa disebut telepon seluler. Pada saat itu telepon seluler belum begitu canggih dan masih terbatas. Karena yang bias memakainya hanya pada saat tertentu dan keperluan-keperluan khusus saja.

Nah, pada saat ini telepon seluler sudah sangat terkenal. Sekarang ini telepon seluler berubah nama menjadi handphone atau lebih singkatnya HP. Tetapi belum begitu canggih. Karena tidak semua orang memilikinya, dan belum dilengkapi kamera dan fitur-fitur yang unik.

Pelayanan telepon seluler dan handphone begitu pesat pertumbuhannya. Hal ini disebabkan oleh tingkat kebebasan dan peningkatan produktivitas yang mampu dilayani oleh teknologi telepon seluler. Dalam perkembangannya juga, terus mucul produk-produk dan model-model handphone terbaru yang teknologinya kian canggih. Dan sudah pasti harganya pun selangit, karena termasuk barang mewah.

Menyadari itu bagi perempuan fatayat, penggunaan telepon selular bukan saja untuk melakukan komunikasi dengan orang tua, guru, teman atau kelompok social perempuan fatayat lainnya. Akan tetapi handphone 
sudah menjadi gaya hidup dan perempuan fatayat harus memilikinya.

$\mathrm{Bu}$ Uswatun hasanah (46 tahun) misalnya seorang ibu rumah tangga berprofesi sebagai guru RA dan salah satu pengurus di fatayat cabang situbondo menceritakan awal berkenalan dengan telepon android dan media sosial;

"saya awalnya juga tidak paham penggunaan HP dan beberapa aplikasi didalamnya, saya menggunakan facebook, whats up dan instagram biar bisa terhubung dengan teman teman yang lain karna hampir semua teman menggunakan facebook, dan hal ini sangat menyenangkan, melalui whats up saya berbagi informasi positif terkait kegiatan organisasi dan lain lain, belum lagi ketika ada berita yang menghibur, HP menjadi hiburan tersendiri"2

Hal tersebut Sebenarnya sebuah alasan sederhana, untuk memsang gambar lucu-lucu merupakan in order to motive bagi perempuan fatayat agar kehidupan mereka di social media dikatakan eksis dan tidak ketingglan zaman. Sebenarnya ada banyak pola hidup yang berubah dalam kehidupan perempuan fatayat dengan smartphonenya. Kemanapun mereka tidak pernah meningggalkan benda satu ini; mulai dari mengisi waktu luang, mengerjakan tugas bahkan sebelum tidur mereka akan menyempatkan untuk member salam pada sahabat social media mereka.

Perempuan sebagai mayoritas penduduk di Indonesia memiliki berbagai keterbatasan untuk dapat lebih aktif dalam ranah publik. Beberapa aspek terkait kondisi lingkungan dan kondisi pribadi perempuan itu sendiri masih membatasi komunikasi atau keikutsertaan perempuan dalam wilayah publik, khususnya politik. Berbagai kendala baik sosial maupun psikologis menjadi hambatan dalam komunikasi langsung.

\section{Literasi Media Untuk Mengelola Konten-Konten Media Sosial Bagi Perempuan Fatayat}

\section{a. Pengenalan literasi Media terhadap Perempuan Fatayat}

Secara sederhana, literasi dapat diartikan sebagai sebuah kemampuan membaca dan menulis. Kita mengenalnya dengan melek aksara atau keberaksaraan. Namun sekarang ini literasi memiliki arti luas, sehingga keberaksaraan bukan lagi bermakna tunggal melainkan mengandung beragam arti (multi literacies). Ada bermacam macam keberaksaraan atau literasi, misalnya literasi komputer (computer literacy), literasi media (media literacy), literasi teknologi (technology

2 Wawancara dengan USwatun hasanah, sepetember 2018

$$
\begin{array}{l|l}
\text { JURNAL LISAN AL-HAL } & 79
\end{array}
$$


literacy), literasi ekonomi (economy literacy), literasi informasi (information literacy), bahkan ada literasi moral (moral literacy). Seorang dikatakan literat jika ia sudah bisa memahami sesuatu karena membaca informasi yang tepat dan melakukan sesuatu berdasarkan pemahamannya terhadap isi bacaan tersebut.

\section{b. Penguatan Literasi Media terhadap Konten Pendidikan Melalui Akun Facebook}

literasi media ditujukan bagi mengumpulkan dan/atau mengolah kembali informasi, mengevaluasi kualitas, relevansi dan kegunaan informasi, serta melakukan pengecakan terhadap keakuratan informasi yang diperoleh.

Beberapa perempuan pengurus fatayat cabang situbondo kurang lebih 10 orang adalah pengguna aktif media sosial facebook. Dengan berbagai pesan atau content yang dishare atau dibagikan ke publik.

Tabel 4.1

Nama nama informan pengguna media sosial facebook

\begin{tabular}{|l|l|l|}
\hline No & Nama & Nama akun facebook \\
\hline 1 & Zeiniye & Zeiniye \\
\hline 2 & Silina & Sillina efendy \\
\hline 3 & Luluk maktumah & Luluk maktumah \\
\hline 4 & Uswatun hasanah & Ana hasanah \\
\hline 5 & Jazillah & Zillah Aqil \\
\hline 6 & Retno afifah & Retno afifah \\
\hline 7 & Ami luki & Ami luki \\
\hline 8 & Ulfiyana & Ulfiyana faisol \\
\hline 9 & Istifadah & Istifadatul khoiroh \\
\hline 10 & Rahmatillah zaini & Rahmatillah zaini \\
\hline
\end{tabular}

Sumber : hasil FGD September 2018

Silina merupakan pengurus fatayat cabang situbondo yang cukup aktif menggunakan akun facebook dalam mengunggah kegiatan-kegiatan pendidikan yang ada dilingkungannya.

$80 \mid$ JURNAL LISAN AL-HAL 


\section{Gambar 4.1. akun facebook Zillah Aqil}

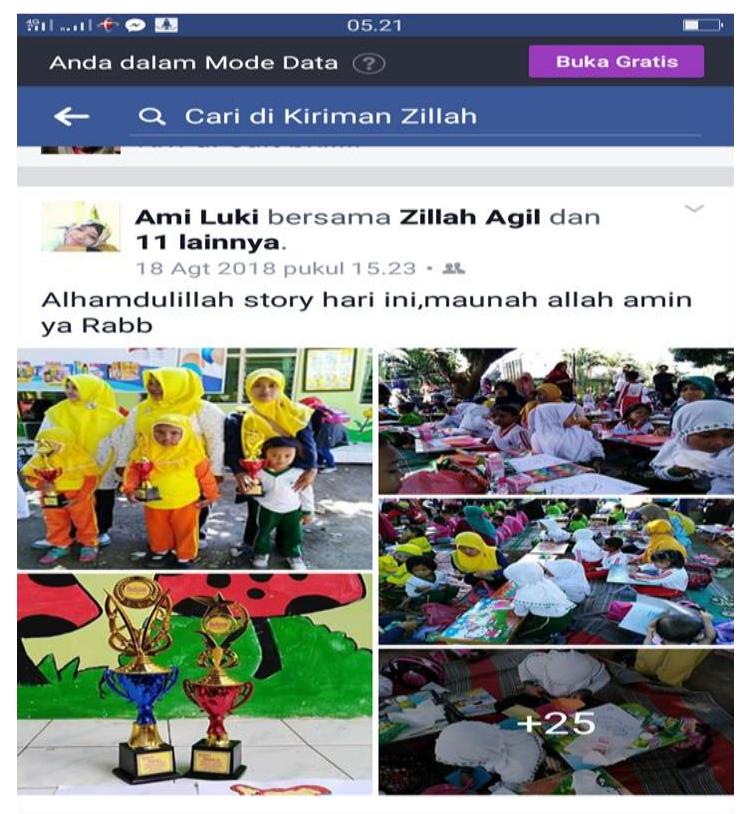

\section{Sumber: wall facebook Sillina efendi}

Organisasi fatayat situbondo sendiri tidak memiliki akun grup facebook atau akun facebook tersendiri, semua informasi terkait organisasi dibagikan melalui grup whats up pengurus Fatayat. Maka tentu saja conten pendidikan melalui media sosial dibagikan oleh pengguna akun facebook seperti sillina effendi, Jazillah pemilik akun Zillah Aqil, uswatun hasanah pemilik akun Ana hasanah dan Istifadah pemilik akun Istifadatul khoiroh.

\section{c. Penguatan Literasi terhadap Conten Ekonomi Melalui Akun Facebook}

Yang dimaksud dengan conten ekonomi adalah pesan pesan yang berkaitan dengan kegiatan ekonomi yang dilakukan oleh pengguna media sosial, baik berkaitan dengan kegiatan pelatihan ekonomi, ekonomi mikro bahkan bisnis online yang menggunakan media sosial sebagai ajang promosi gratis. Luluk maktumah sebagai coordinator devisi ekonomi dalam kepengurusan fatayat cabang situbondo lebih sering menggunakan media whats up untuk berbagi informasi ekonomi terhadap anggota fatayat. 
Selain luluk maktumah, istifadah pemilik akun facebook istifadatul khoiroh adalah yang menggunakan media sosial facebook untuk berjualan online, mulai dari pakaian, kosmetik dan produk makanan dipasarkan melalui dinding facebooknya

Disadari oleh istifadah bahwa facebook sangat potensial untuk melakukan promosi gratis, cepat dan dibaca oleh banyak orang maka peluang usaha dalam membangun bisnis online dicobanya.

"sebenarnya market saya lebih pada teman-teman yang terhubung pertemanan dengan saya baik di media sosial maupun lingkungan sosial, kita sudah sama-sama kenal jadi saling percaya dan tidak aka nada aksi tipu tipu, maka konsumen online saya sebenarnya banyak dari kalangan yang saya kenal secara dekat" 3

\section{d. Konten Pribadi Melalui Akun Facebook}

Kebutuhan eksistensi diri bagi perempuan ditunjukkan dengan berbagi kegiatan yang dilakukan sehari hari, muali dari ruang pribadi dan ruang keluarga. Berbagi gambar anggota keluarga, suami, anak anak dan orang tua menjadi bagian yang tak terpisahkan dalam pengguna akun facebook. Misalnya pada pemilik akun Zillah Aqil, menampilkan foto pribadi yang sangat cantik, sehingga mengundang orang/nitizen untuk berkomentar "cantiknya mbak Zillah Aqil".

\section{e. Konten Organisasi Melalui Akun Facebook}

Keberadaan Fatayat di Situbondo diharapkan bisa membawa perubahan terhadap situasi sosial dan budaya termasuk terhadap perempuan itu sendiri. Melalui berbagai kegiatan positif perempuan melalui organisasi fatayat belajar banyak hal. Berbagi infromasi organisasi fatayat kabupaten situbondo, dibagikan oleh para pengurus secara pribadi melalui akunnya, Sillina Efendi, ana hasanah, zeiniye dengan cara menandai satu sama lainnya. Berbagai kegiatan seperti workshop dan kegiatan bakti sosial yang dilakukan di akhir bulan September 2018.

${ }^{3}$ Wawancara istifadah, sepetember 2018

82 JURNAL LISAN AL-HAL 


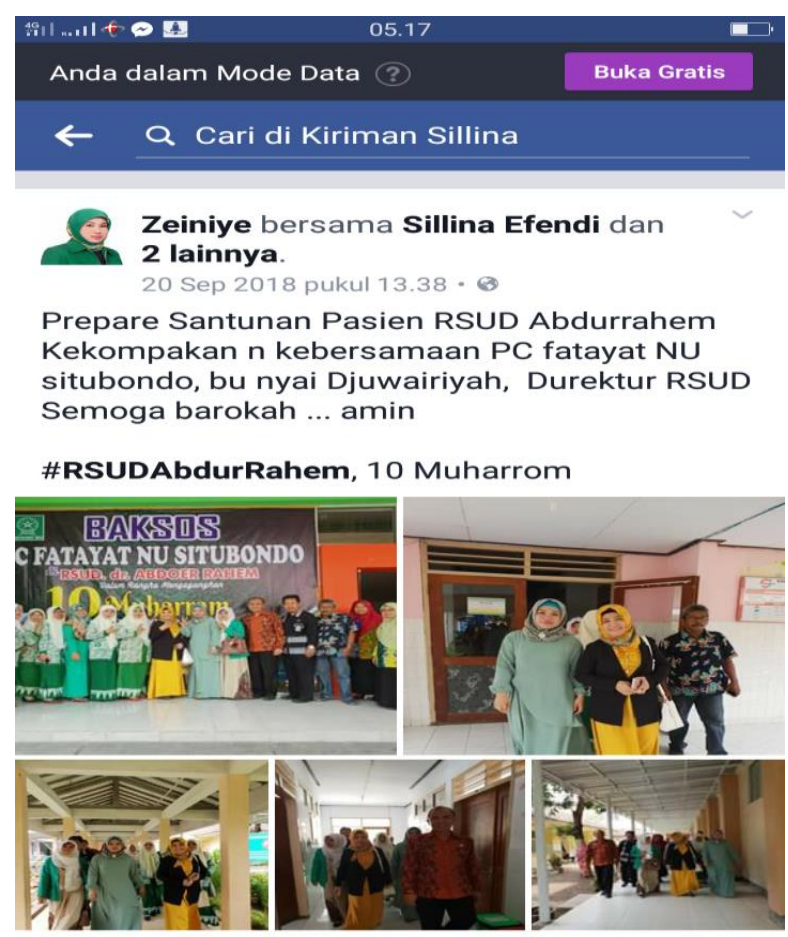

Gambar akun. Sillina effendi

\section{f. Konten Politik Melalui Akun Facebook}

Lemahnya pengetahuan dan mental perempuan ini tentu semakin menyulitkan kaum perempuan dalam mengakases informasi dan menyampaikan informasi di depan public. Perasaaan minder dan tidak memiliki pengetahuan yang cukup maka perempuan tak berani berbicara di depan media. Tentu saja ini menjadi kesempatan laki-laki yang mengisi media untuk berkomunikasi secara politik.

Pada PEMILU 2014 misalnya betapa kemudian beberapa partai politik sangat kesulitan ketika harus memenuhi kuato 30\% caleg (calon legislative) perempuan. Sehingga beberapa partai politik cenderung "ngawur" dalam menyeleksi caleg perempuan.Hal ini menunjukkan bahwa sebenarnya beberapa partai gagal dalam kaderisasi perempuan. Pemahaman keadilan gender tidak begitu menyentuh wilayah politik. Meskipun pada pemilu legislative 2009 DPRD Situbondo dipimpin oleh Ketua Perempuan akan tetapi belum bisa memberikan perubahan yang signifikan dalam etika media sosial perempuan di Situbondo. Ketidakmampuan perempuan dalam etika media sosial ini akhirnya hanya menjadikan Keterlibatan perempuan sebagai pemilih dan belum pada posisi strategis akan tetapi seolah sebagai pelengkap saja. 
Facebook menjadi sarana propaganda yang gratis dan potensial untuk melakukan kampanye dan sosialisai politik. Beberapa dari perempuan pengurus fatayat sedang berlaga di kancah politik seperti Zeiniye yang saat ini menjadi anggota DPRD kab Situbondo dan merupakan wakil ketua dewan. Dan Istifadatul khoiroh termasuk maju dalam pilkada 2019.

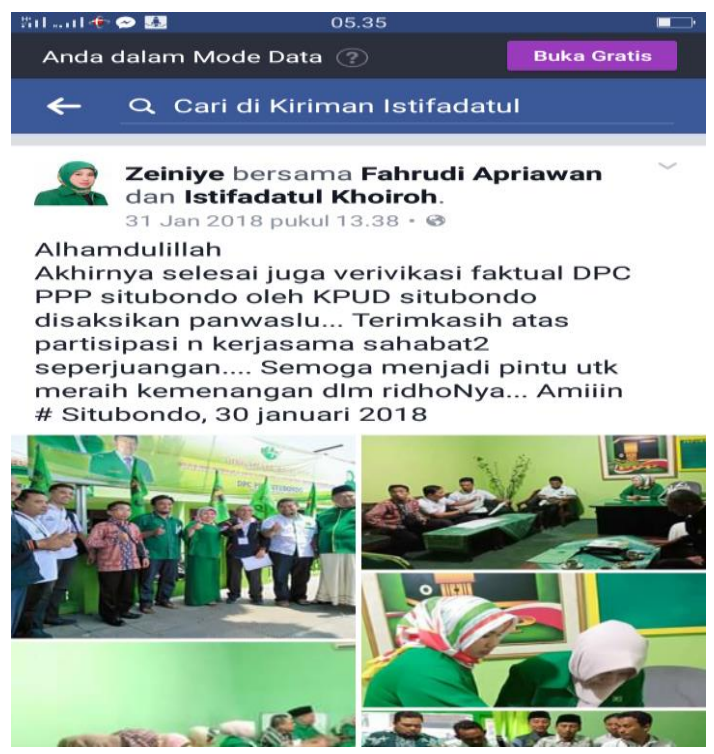

Sumber: Akun Facebook Zeiniye

\section{Penguatan Pengetahuan Literasi Media terhadap Perempuan dengan Etika Media Sosial}

a. Media Sosial sebagai Jejaring Bagi Perempuan Fatayat

Fungsi dari jejaring sosial memang sangat bermanfaat di era globalisasi seperti ini, semakin lama fungsi jejaring sosial pun bertambah. Contohnya, jejaring sosial Facebook. Selain kita dapat menambah teman dari lain sekolah, lain kota atau lain negara, dengan facebook kita bisa memasukkan dan berbagi foto atau apapun dengan pengguna Facebook lainnya, Facebook juga menyediakan permainan-permainan online untuk para penggunanya, dan banyak juga yang memanfaatkan Facebook sebagai lahan bisnis untuk menjual berbagai macam barang dengan transaksi online. Menurut mereka, berbisnis di Facebook sangatlah membantu karena lebih mudah untuk mempromosikan barang-barang yang akan mereka jual dan bisa melakukan transaksi kapan saja. Begitu juga para pembeli atau pengguna Facebook yang suka berbelanja, melalui Facebook mereka juga tidak harus capek-capek pergi ke toko untuk

$84 \mid$ JURNAL LISAN AL-HAL 
sekedar melihat-lihat barang atau membeli barang, transaksi juga lebih mudah, dan barang-barang yang dibeli pun mempunyai kualitas yang tidak kalah baik dengan yang ada ditoko-toko biasa. Yah, memang dengan mudahnya transaksi yang dilakukan kita tetap harus berhati-hati sewaktu melakukan transaksi. Karena semakin banyak kegunaannya, saat ini sudah banyak pengguna Facebook dari kalangan orangtua dan anak-anak, bahkan yang masih duduk di bangku Taman Kanak-kanak atau Sekolah Dasar.

Lain halnya dengan jejaring sosial Twitter yang akhir-akhir ini kebanjiran pengguna baru dan menjadi tren, meskipun pada dasarnya Twitter mempunyai fungsi yang sama dengan Facebook, para pengguna jejaring sosial ini tidak dapat berbagi foto, bermain permainan, atau berbisnis. Twitter lebih digunakan untuk sekedar berbincang-bincang melalui akun dengan cara memention pengguna lain. Kelebihan Twitter bagi para penggunanya yang hampir semua adalah perempuan fatayat, yaitu mereka bisa mendapat informasi lebih cepat tentang pembicaraan apa yang sedang tren didunia, mendukung acara, artis atau apapun. Para perempuan fatayat juga menggunakan akunnya untuk menulis apa yang sedang mereka lakuan, keberadaan mereka disuatu tempat atau curhat (mengungkapkan perasaan), dari masalah pribadi, teman, sekolah, pacar hingga orangtua. Para perempuan fatayat lebih memilih menggunakan Twitter, karena Twitter sifatnya lebih tertutup dibandingkan dengan Facebook, alasan lainnya adalah karena orangtua mereka tidak mempunyai akun dan belum mengerti cara menggunakan Twitter. Itu sudah membuktikan bahwa kehidupan sebagian besar perempuan fatayat pada saat ini sudah sangat lekat pada jejaring sosial dan sudah menjadi bagian dari hidup mereka.

Saat ini, bisa dibilang sebagian besar perempuan fatayat sudah menggunakan Smartphone. Mereka mendapatkan banyak manfaat, dapat menghubungi teman lebih mudah, mengakses akun jejaring sosial atau blog mereka langsung ditangan mereka sendiri, mencari bahan pelajaran dari situs-situs diinternet tanpa harus merasa kurang nyaman atau terlihat kecil. Akan tetapi, lama-kelamaan perempuan fatayat perempuan fatayat pengguna Smartphone ini terkena dampak negatif. Bagaimana tidak? Dengan kemudahan yang diberikan oleh Smartphone, para perempuan fatayat menjadi autis. Autis bukan berarti mereka cacat dari lahir, tetapi berarti mereka tidak dapat berbuat apa-apa ketika sedang berkutat dengan Smartphonenya, mereka akan selalu mengakses akun mereka, memeriksa apakah ada balasan atau pesan, atau bahkan hanya sekedar melihat-lihat akun mereka. Dengan begitu secara tidak sadar mereka

$$
\begin{array}{l|l}
\text { JURNAL LISAN AL-HAL } & 85
\end{array}
$$


selalu mengutamakan dan terpaku pada Smartphone mereka. Faktanya sudah sangat nyata, dimana-mana kita bisa temukan para pengguna Smartphone selalu membawa Smartphone ditangan mereka kemanapun mereka pergi, membuka Smartphone mereka sesering mungkin dan mengakses akun-akun mereka setiap saat bahkan disaat makan, tidur, dan didalam kelaspun. Kecelakaan yang disebabkan akibat pengguna jalan yang terlalu asik dengan smartphonenya juga sudah banyak terjadi. Hal inilah yang sangat menyedihkan dan mengkhawatirkan, terutama bagi para pelajar, mereka menjadi sangat tidak fokus dengan kewajibannya. Waktu mereka sehari-hari sebagian besar dihabiskan didepan Handphone android.

Realitas penggunaan jejaring sosial diluar batas dan tidak semestinya, sudah menimbulkan banyak kasus dimana-mana, penculikan anak dibawah umur tingkat SMP dan SMA yang bermula dari Facebook sudah menelan banyak korban, banyak juga pengguna Facebook yang tidak mencantumkan data diri asli dan berujung pada masalah ke pengguna lain, pertengkaran yang disebabkan masalah kecil akibat kalimat-kalimat atau kata-kata yang menyinggung diakun jejaring sosial, menjalin hubungan dengan orang lain dijejaring sosial meskipun belum pernah bertemu langsung juga sudah menimbulkan masalah, para perempuan fatayat juga merasa lebih nyaman menumpahkan isi hatinya didalam akun mereka daripada bercerita langsung ke orangtuanya.

Dengan adanya masalah-masalah yang timbul dan akibat penggunaan jejaring sosial dan ketergantungan para perempuan fatayat pada Smartphone, para perempuan fatayat yaitu pelajar dan mahaperempuan harus pintar-pintar menempatkan diri. Mereka harus sadar agar tidak diperbudak oleh kemajuan teknologi yang ada. Bukan berarti para perempuan fatayat dilarang mengakses jejaring sosial dan menggunakan Smartphone, mereka hanya harus tetap memproiritaskan kewajiban mereka, dengan selalu mengingat waktu, menahan diri, dan tetap menjalin pertemanan dan hubungan secara langsung didunia nyata. Hubungan dengan orang tuapun juga harus selalu dijaga karena bagaimanapun diusia perempuan fatayat ini kita susah menahan diri kita sendiri apalagi di era-globalisasi seperti ini dimana kemajuan teknologi sangat pesat.

Dewasa ini perkembangan di bidang teknologi informasi merupakan dampak dari semakin kompleksnya kebutuhan manusia akan informasi itu sendiri. Kebutuhan akan pentingnya informasi bagi setiap individu, demikian pula pada perempuan fatayat di sekolah menengah atas yang memanfaatkan kemudahan akses informasi untuk belajar

86 JURNAL LISAN AL-HAL 
maupun mengerjakan pekerjaan rumah yang di berikan oleh guru di sekolah. Media Smartphone yang ada dapat dirasakan oleh perempuan fatayat untuk menelusur informasi Media Smartphone yang ada dapat dirasakan oleh perempuan fatayat untuk menelusur informasi. Belajar dengan melibatkan informasi dalam berbagai media yang semakin menunjukkan pengaruhnya terhadap belajar ${ }^{4}$. Masyarakat informasi adalah masyarakat yang memiliki karakteristik dan familiar akan penggunaan piranti Teknologi Informasi dan tak lagi canggung untuk melakukan interaksi meskipun untuk kalangan perempuan fatayat kemudian mereka seringkali menghabiskan banyak waktu untuk menggunakan handphone untuk berinternet daripada melakukan kegiatan sehari-hari, mereka cenderung mengesampingkan kegiatan utama dan memilih untuk berkomunikasi dengan handphone mereka dan melakukan jejaring sosial dan menjadikann aktifitas tersebut sebagai aktifitas yang menyenangkan melebihi aktivitas menonton televisi.

Dekatnya hubungan antara informasi dan teknologi jaringan komunikasi telah menghasilkan dunia maya yang amat luas yang biasa disebut dengan teknologi cyberspace. Teknologi ini berisikan kumpulan informasi yang dapat diakses oleh semua orang dalam bentuk jaringan-jaringan komputer yang disebut jaringan internet.

Sebagai media penyedia informasi, internet juga merupakan sarana kegiatan komunitas komersial terbesar dan terpesat pertumbuhannya. Sistem jaringan memungkinkan setiap orang dapat mengetahui dan mengirimkan informasi secara cepat dan menghilangkan batas-batas teritorial suatu wilayah negara. Kepentingan yang ada bukan lagi sebatas kepentingan suatu bangsa semata, melainkan juga kepentingan regional bahkan internasional.

Perkembangan teknologi informasi, dengan media sosial sebagai salah satu produk yang mendorong keterbukaan informasi dan kebebasan berpendapat, telah membawa pengaruh besar bagi dinamika kehidupan masyarakat masa kini. Akan tetapi, perkembangan ini juga diikuti dengan dampak negatif yang perlu menjadi perhatian dan mendorong perlunya regulasi yang dapat mengontrol para pengguna. Dengan Keberadaan teknologi kini memiliki peranan yang sangat besar terutama dalam proses pembelajaran di dunia pendidikan. Berbagai kemudahan didapatkan setelah adanya penggunaan teknologi informasi. Kemudahan tersebut dapat dirasakan oleh pihak pengajar maupun pihak yang tengah belajar.

4 Pawit, M Yusup. Ilmu Informasi, Komunikasi dan Kepustakaan. (Jakarta:Bumi Aksara. 2009). 
Tentu kemajuan teknologi ini menyebabkan perubahan yang begitu besar pada kehidupan umat manusia dengan segala peradaban dan kebudayaannya. Perubahan ini juga memberikan dampak yang begitu besar terhadap transformasi nilai-nilai yang ada di masyarakat. Khususnya masyarakat dengan budaya dan adat ketimuran seperti Indonesia.

Dalam perkembangannya, berbagai media rekreasi dengan perangkat teknologi menjadi bagian dalam hidup warga masyarakat. ${ }^{5}$ Saat ini, di Indonesia dapat kita saksikan begitu besar pengaruh kemajuan teknologi terhadap nilai-nilai kebudayaan yang di anut masyarakat, baik masyarakat perkotaan maupun pedesaan (modernisasi).

Pesatnya perkembangan teknologi yang terkandung di dalam Smartphone saat ini merupakan dampak dari semakin kompleksnya kebutuhan manusia akan informasi itu sendiri. Dekatnya hubungan antara informasi dan teknologi jaringan komunikasi telah menghasilkan dunia maya yang amat luas yang biasa disebut dengan teknologi cyberspace. Teknologi ini berisikan kumpulan informasi yang dapat diakses oleh semua orang dalam bentuk jaringan-jaringan internet yang terdapat pada Smartphone. Sebagai media komunikasi Smartphone juga merupakan sarana kegiatan komunitas komersial terbesar dan terpesat pertumbuhannya. Sistem jaringan memungkinkan setiap orang dapat mengetahui dan mengirimkan informasi secara cepat dalam satu genggaman. Lahirnya era komunikasi interaktif di tandai dengan terjadinya diversivikasi teknologi informasi dengan bergabungnya telepon, radio, komputer, dan televisi menjadi satu dan menandai teknologi yang disebut internet. ${ }^{6}$ Dengan internet sebagai jantung pada handphone yang memudahkan kita untuk berselancar di dunia maya. Di era digital seperti saat ini, ilmu pengetahuan semakin berkembang. Manusia menciptakan hal - hal baru dalam bentuk non fisik maupun fisik, dalam bentuk non fisik lahirnya generasi internet yang dapat memudahkan kita dalam mengakses informasi, sedangkan dalam bentuk fisik terciptanya Smartphone sebagai alat komunikasi ini merupakan salah satu bentuk akan kemajuan ilmu pengetahuan khususnya pada bidang teknologi informasi.

\footnotetext{
${ }^{5}$ Subandy,Idi. Ecstasy Gaya Hidup: Kebudayaan Pop dalam "Masyarakat Komoditas" (Indonesia.Mizan Pustaka: Bandung. 1997)

${ }^{6}$ Bungin,Burhan. Sosiologi Komunikasi: Teori, Paradigma, dan Diskursus Teknologi komunikasi di Masyarakat. (Kencana: Jakarta. 2006) 


\section{b. Media Sosial sebagai Media Informasi Pendidikan Bagi Perempuan Fatayat}

Media informasi pendidikan merupakan Media pendidikan merupakan alat yang digunakan dalam rangka proses belajar mengajar untuk memperoleh tujuan pembelajaran yang diinginkan. Hal ini kemudian dirumuskan dalam konsep media pembelajaran yang digunakan di lembaga-lembaga pendidikan. Begitupun media informasi merupakan alat untuk memberikan informasi utuh dengan tujuan penerima informasi memahami maksud dari informasi yang diterima tanpa adanya perbedaan makna.

Banyak batasan yang diberikan orang tentang media. Assosiasi Teknologi dan Komunikasi Pendidikan (Assosiation of education and communication) di Amerika misalnya membatasi media sebagai segala bentuk dan saluran yang digunakan orang untuk menyampaikan pesan atau informasi. Fleming dalam Arsyad mengungkapkan bahwa media atau mediator adalah penyebab atau alat yang turut campur tangan dalam dua pihak dan mendamaikannya. Sementara itu Gerlach dan Ely seperti yang dikutip oleh Arsyad mendifinisikan media secara garis besar, bahwa media adalah manusia, materi, atau kejadian yang membangun kondisi yang membuat perempuan mampu memperoleh pengetahuan ketrampilan atau sikap. $^{7}$

Media mempunyai arti penting dalam dunia pendidikan, terutama dalam pendidikan formal di sekolah. Guru sebagai pengajar dan sekaligus sebagai pendidik yang terjun langsung dalam dunia pendidikan formal di sekolah, tidak meragukan lagi akan keampuhan suatu media pembelajaran. Utamanya menanamkan sikap dan mengharapan perubahan tingkah laku seperti yang diharapkan, yaitu yang sesuai dengan tujuan pembelajaran. ${ }^{8}$

Kata media berasal dari bahasa latin yang merupakan bentuk jamak dari kata medium yang secara harfiah berarti perantara atau pengantar. Medium adalah perantara atau pengantar pesan dari pengirim ke penerima pesan. ${ }^{9}$

Dalam konteks belajar dan pembelajaran, media dapat diartikan sebagai segala sesuatu yang dapat menyalurkan pesan atau materi ajaran

${ }^{7}$ Azhar Arsyad, Media Pembelajaran, (Jakarta: PT RajaGrafindo Persada, 2008), 3. 2001), 57.

8Yoto dan Saiful Rahman, Manajemen Pembelajaran, (Malang: Yanizar Group,

${ }^{9}$ Arief S. Sadiman dkk, Media Pendidikan Pengertian, Pengembangan, dan Pemanfaatannya, (Jakarta: PT Rajagrafindo, 2008), 6. 
dari guru sebagai komunikator kepada perempuan sebagai komunikan. ${ }^{10}$

Media merupakan suatu yang bersifat menyalurkan pesan dan dapat merangsang pikiran, perasaan, dan kemampuan audien (perempuan) sehingga dapat mendorong terjadinya proses belajar pada dirinya. ${ }^{11}$ Menurut Biggs yang dikutip oleh Sadiman bahwa; "Media adalah segala alat fisik yang dapat menjadikan pesan serta merangsang perempuan untuk belajar."12

Pengertian media pembelajaran itu sama dengan media pendidikan, hal itu sesuai dengan Oemar Hamalik yang mengatakan bahwa yang dimaksud media adalah alat, metode dan teknik yang digunakan dalam rangka lebih mengefektifkan komunikasi dan interaksi antara guru dan perempuan dalam proses pendidikan dan pengajaran di sekolah. ${ }^{13}$

Media sosial adalah sebuah media yang isinya diciptakan dan didistribusikan melalui sebuah interaksi sosial. Media sosial merupakan sebuah aplikasi yang mengijinkan penggunanya berinteraksi dan memberikan timbal balik dengan sesama pengguna; membuat, mengedit dan membagikan informasi dalam berbagai bentuk (Prof. Neil Selwyn ,2012). Pertumbuhan media sosial selama beberapa tahun terakhir telah membawa perubahan cara pemanfaatan internet bagi penggunanya dalam dunia pendidikan. Media sosial dalam interaksi sosial secara fungsinya dikondisikan sebagai bentuk kolaborasi, keramahan, dan kreativitas penggunanya.

Beberapa orang perempuan yang hadir dalam rapat harian fatayat misalya pernah mengalami ketinggalan handphone di rumah, yang dirasakan adalah

" saya seperti orang yang bigung tidak tahu harus melakukan apa ketika handphone tidak ditangan, menoleh ke kanan dan kekiri, gelisah dan lain lain. Rasanya kok hampa ketika handphone ketinggalan"14

Media sosial memiliki daya tariknya sendiri bagi setiap kalangan, begitupula dengan kalangan perempuan fatayat . Berdasarkan hasil riset yang dilakukan oleh kementrian Kominfo dalam penelusuran para pengguna aktivitas online pada anak usia perempuan fatayat tahun 2014,

$10 \mathrm{http}: / /$ ppraudlatulmubtadiin.wordpress.com, diakses tanggal 11 Maret 2011

11 Asnawir, Basyirudin Usman, Media Pembelajaran, (Jakarta: Ciputat Press, 2002). 11.

12 Arief S. Sadiman dkk, Media Pendidikan: Pengertian, Pengembangan, dan Pemanfaatannya, (Jakarta: PT RajaGrafindo Persada, 2008). 6.

13 Oemar Hamalik, Media Pendidikan, (Bandung: Citra Aditiya Bakti, 1989), 12.

14 Wawancara dengan uswataun hasanah, september 2018

$90 \quad$ JURNAL LISAN AL-HAL 
ditarik kesimpulan bahwa penggunaan media sosial sangat melekat dengan kehidupan perempuan fatayat sehari-hari. Dalam studi ini ditemukan bahwa dari 98 persen perempuan fatayat yang di survei tahu tentang internet dan 79,5 persen diantaranya adalah pengguna internet.

Kehidupan perempuan fatayat memiliki potensi selalu tidak ingin lepas dari sesuatu hal yang baru, tak bisa dipungkiri bahwa kehidupan perempuan fatayat adalah masa dimana manusia dengan segala potensinya berupaya dengan motivasi yang kuat untuk mengembangkan potensi yang dimiliki dengan memanfaatkan instrumen-instrumen yang mendukung proses pengembangan potensi pada dirinya secara bijak, meskipun memiliki potensi kecenderungan untuk menyimpang dari norma yang mapan, tetapi pola fikir kaum perempuan fatayat juga memiliki kecenderungan yang sangat potensial untuk mengembangkan pola fikirnya kearah kehidupanyang positif walaupun tantangan zaman yang begitu kuat. Media sosial dalam kehidupan perempuan fatayat membawa dan membentuk semacam dunia baru dalam pola fikir perempuan fatayat dalam berinteraksi dan berkomunikasi dengan cara yang baru, terutama dalam dunia pendidikan, media yang memberikan kemudahan dalam proses pendidikan, disadari atau tidak media sosial telah berhasil menjawab tantangan tersebut dan media sosial telah berhasil memenuhi harapan para perempuan fatayat dengan menyajikan berbagai informasi-informasi edukatif yang luas dari berbagai aspek, salah satu fitur edukatif dari media social yang sering di manfaatkan para kalangan perempuan fatayat dalam mencari informasi-informasi edukatif adalah Wikipedia, boleh dikatakan bahwa Wikipedia adalah Ensiklopedia pengetahuan yangpaling lengkap di dunia maya. JAzilah yang juga berprofesi sebagai guru dan Luluk Maktumah yang seorang dosen adalah perempuan fatayat yang cukup aktif memanfaatkan fitur -fitur yang berisikan informasi pendidikan;

"segala kebutuhan informasi hampir ssemua kita Tanya dan gunakan Google, informasi pendidikan, hiburan, politik, sosial budaya, agama bahkan gossip artis dan film semua kita gunakan google, dan benar semua disediakan, untuk bahan mengajar saya akses menggunakan google dan beberpa aplikasi lain, jadi memang semua terasa mudah" 15

15 Wawancara dengan luluk maktumah, September 2018 


\section{Penguatan Etika Media Sosial terhadap Perempuan Fatayat melalui Pendidikan Literasi Media}

Pendidikan literasi terhadap perempuan membutuhkan waktu yang panjang dan lama. Terlebih tradisi membaca sangat kurang diminati oleh prempuan, akan tetapi pengalaman selalu mengajarkan dan menjadi guru terbaik bagi perempuan. Belajar dari kasus perempuan $\mathrm{Z}$ di media sosial ketika menjadikan gempa situbondo September lalu sebagai sebuah "guyonan" membawa perempuan ini pada ranah hukum karena melanggar undang undang ITE. Kasus yang kedua adalah kasus "pelecehan ulama" terhadap Kyai Azaim yang merupakan pengasuh pondok pesantren Salafiyah safiiyah Sukorejo situbondo yang dilakukan oleh pemuda asal desa Mangaran Situbondo juga menyeretnya ke ranah hokum.

Belajar dari beberapa kasus ini perempuan fatayat sadar betapa harus"bijak dan hati hati " menggunakan media sosial. Maka beberapa langkah yang dilakukan oleh prempuan fatayat dalam rangka penguatan etika media sosial adalah belajar literasi media atau pengenalan media khususnya media sosial.

\section{a. Rapat rutin dan diskusi tematik}

Terlepas dari berbagai bentuk komunikasi dalam etika media sosial yang bisa dilakukan oleh perempuan, sama halnya dengan laki-laki, perempuan juga dapat berperan sebagai komunikator politik. Dari hasil observasi dan penelitian, perempuan di Fatayat Situbondo melakukan perannya sebagai komunikator media sosial memiliki kebebasan dalam memberikan pesan organisasi, agama, politik, ekonomi dan lainnya. Dalam Pesan politik misalnya berisi dukungan terhadap partai politik dan calon anggota legislatif yang merupakan teman atau kerabat. Maka perempuan dalam kegiatan rapat melakukan peran politik perempuan sebagai komunikator politik dengan menyaring aspirasi dan mencoba menggulirkan isu-isu yang krusial di masyarakat untuk kemudian melakukan advokasi kepada pihak-pihak yang berkepentingan untuk dicari solusinya.

"Itu yang baru kita bangun. Jadi seperti saya sampaikan pada perempuan Fatayat, seringkali masyarakat itu belum memberikan pendapat/ belum berani menyampaikan pendapat. Sebenarnya kita menampung sekali kalau ada aspirasi dari masyarakat, tapi seringkali, terutama perempuan tidak mau usul meskipun ditawari. Itu yang baru kita bangun, bahwa silahkan ibu-ibu punya pendapat, usulan atau mungkin permasalahan yang bisa disampaikan. Maka kita sampaikan ke atas, mungkin ke pihak yang berkaitan. Sebenarnya itu

92 JURNAL LISAN AL-HAL 
sudah kita buka, Cuma seringkali mereka sendiri yang belum menyampaikan," jelas Zeiniye. ${ }^{16}$.

Perempuan sebagai komunikator politik partai yang melakukan promosi partai merupakan fenomena yang lazim. Dari banyaknya penduduk Indonesia yang mayoritas perempuan hingga isu-isu gender yang kerap membangkitkan khalayak politik perempuan. Dengan begitu, maka komunikator politik perempuan dianggap lebih mengerti mengerti masalah perempuan dan sesuai dengan perjuangan kaum perempuan dalam menegakkan hak-haknya.

Perempuan di Fatayat Situbondo melakukan perannya sebagai komunikator politik dengan menjadi penghubung antara masyarakat dengan partai dan pemerintah. Kegiatan perempuan di kepengurusan Fatayat Situbondo sebagai komunikator politik diantaranya dilakukan dengan menghubungi pejabat pembuat kebijakan, serta melakukan etika media sosial melalui media lain seperti rapat partai atau mengikuti konsolidasi dengan organisasi kepentingan lain yang sesuai dengan kepentingan mereka.

Asumsi tentang perempuan tersebut tidak terkecuali bagi perempuan Situbondo. perempuan Situbondo menghadapi persoalan yang lebih komplek terkait dengan persepsi budaya, agama, social dan politik. Maka perempuan harus belajar etika media sosial untuk menghadapi tantangan dunia baru yaitu teknologi informasi.

Melalui diskusi tematik yang dibahas bersma sama dalam FGD, akhirnya mengekplor kegelisahan dan persoalan -persoalan yang dihadapi oleh perempuan melalui media sosial. Mulai dari bagaimana perempuan memanfaatkan media dan dimanfaatkan oleh media sosial.

\section{b. Perempuan Belajar ETIKA melalui media sosial}

Akun media sosial seperti Facebook menjadi media belajar etika bagi perempuan, dalam conten politik misalanya, dengan pemahaman sederhana perempuan kota fatayat:

"untuk apa bertengkar untuk urusan politik, saya ini perempuan yang tidak paham apa apa bagi saya pilihan kyai dan bunyai sebagi guru saya tentu pilihan yang terbaik baik itu partai maupun pemilihan kepala daerah. Bagi saya berpolitik adalah berpartisipasi dalam setiap proses demokrasi yang diselenggarakan oleh pemerintah. Menghorrmati perbedaan pilihan adalah hal baik "jek atokaran gara gara pemilu lima taon sakalean, amoso ben tatangge ben masyarakat

16 Wawancara tanggal 03 September 2018 
sampek lema taon" (jangan bertengkar gara-gara pemilu lima tahun sekali, bermusuhan dengan tetangga selama lima tahun). ${ }^{17}$

Partisipasi perempuan baik sebagai pemilih maupun terpilih memiliki prean signifikan. Perempuan sebagai pemilih dalam pemilu misalnya lebih mengedepankan figur yang dipilih oleh kyai dan bunyai dengan anggapan bahwa kyai dan bu nyai adalah orang yang tidak mungkin salah memilih. Kemudian perempuan sebagai orang yang akan "dipilih" dalam pemilu lebih mengedepankan pandangan bahwa apa yang menjadi pandangan agama, budaya kota fatayat dimana kyai memiliki pengaruh luar biasa dijadikan figur politik yang sangt dihormati setiap keputusan-keputusannya.

\section{E. Simpulan}

Media sosial dalam kehidupan perempuan fatayat membawa dan membentuk semacam dunia baru dalam pola fikir perempuan fatayat dalam berinteraksi dan berkomunikasi dengan cara yang baru, terutama dalam dunia pendidikan, sebagai pelajar tentunya para perempuan fatayat mengharapkan semacam media yang memberikan kemudahan dalam proses pendidikan, disadari atau tidak media sosial telah berhasil menjawab tantangan tersebut dan media sosial telah berhasil memenuhi harapan para perempuan fatayat sebagai pelajar dengan menyajikan berbagai informasi-informasi edukatif yang luas dari berbagai aspek, salah satu fitur edukatif dari media social yang sering di manfaatkan para kalangan perempuan fatayat dalam mencari informasi-informasi edukatif adalah Wikipedia, boleh dikatakan bahwa Wikipedia adalah Ensiklopedia pengetahuan yangpaling lengkap di dunia maya.

Mengelola conten conten melalui facebook yang dishare dan dipublikasikan oleh anggota fatayat, menjadikan mereka belajar literasi secara perlahan. Karena pada akhirnya pengalaman yang dibaca melali media sosial terkait beberapa kasus pelanggaran ITE membuat perempuan belajar hati hati dalam penggunaan media sosial.

Penguatan etika media sosial melalui literasi media dilakukan dengan berbagai tahapan yakni, melalui rapat bulanan, diskusi tematik dan peran perempuan melalui organsisai fatayat. Media sosial sebagi media jejaring yakni sebuah media untuk membangun komunikasi dengan sesama penggunanya oleh perempuan fatayat. Media jejaring ini digunakan dengan berbagai tujuan meliputi tujuan komunikasi,

17 Wawancara dengan ketua fatayat mbak wawik September 2018

94 JURNAL LISAN AL-HAL 
perkenalan, bisnis, pencarian informasi penting dan membangun komunikasi dengan pengguna jejaring lainnya.

\section{DAFTAR PUSTAKA}

Bungin, Burhan. Penelitian Kualitatif Komunikasi, Ekonomi, Kebijakan

Publik, dan Ilmu Sosial Lainnya. Jakarta: Kencana. 2007. Teknologi Komunikasi di Masyarakat. Jakarta: Kencana. 2007.

Littlejohn, Stephen W. Theories of Human Communication. Canada: Wadsworth. 2004.

Kramarae, Cheris, the Muted Group Theory dalam West, Richard dan Lynn H. Turner. Pengantar Teori Komunikasi: Analisis dan Aplikasi (Terjemahan Maria Natalia Damayanti Maer). Jakarta: Salemba Humanika. 2008.

McLuhan, M. Understanding Media. Massachusetts: MIT Press. 1994.

Harjanto, Perencanaan Pengajaran Jakarta: PT Asdi Mahasatya, 2006.

Mulyana, Deddy. Metodologi Penelitian Kualitatif: Paradigma Baru Ilmu Komunikasi dan Ilmu Sosial Lainnya. Bandung: Remaja Rosdakarya. 2006.

Moelong, L.J. Metode Penelitian Kualitatif. Bandung: Remaja Rosdakarya. 2002.

Mulyana, Dedy. Ilmu Komunikasi Suatu Pengantar, Bandung:. Remaja Rosdakarya. 2003.

Sukidin, Basrowi. Metode Penelitian Kualitatif Perspektif Mikro. Surabaya: Insan Cendikia. 2002.

Tannen, Deborah. Anda Hanya Belum Paham: Percakapan antara Pria dan Wanita (Terjemahan Sumarjinah S). Jakarta: Kentindo Soho. 1998.

Straubhaar,LaRose, Media Now.United Stated:Thomson Wadsworth. 2006.

West, Richard dan Lynn H. Turner. Pengantar Teori Komunikasi: Analisis dan Aplikasi (Terjemahan Maria Natalia Damayanti Maer). Jakarta: Salemba Humanika. 2008.

Di Maggio, P., dkk. Social Implications of the Internet. Annual Review of Sociology, 2001.

Hobbs, R. Media Literacy, Media Activism. Telemedium. the Journal of Media Literacy, 1996.

Hobbs, R. The seven great debates in the media literacy movement. Journal of Communication, 48 (1), 1998.

Prensky, M. Digital Natives, Digital Immigrants. On the Horizon, 9 (5), 2001.

Rubin, A. Media Literacy: Editor's note. Journal of Communication, 48 (1),

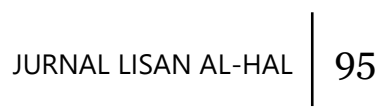


1998.

Rahmi, A. Pengenalan Literasi Media pada Anak Usia Sekolah Dasar. Sawwa, 8 (2), 2013.

Rehia, K.I barus DKK mengenai "Pemberdayaan Perempuan Melalui Media Sosial" (jurnal simbalika/voleme 1/nomer 2/ september 2015.

Tuti Andriyani “Media Massa dan Konstruksi Gaya Hidup Perempuan" 2013.

Dessi Trisilowati, Perempuan dan Media Sosial Sebagai Pilihan Komunikasi Terkini. 2014.

Daher, M. Women enpowerment and through teknology and social media. Lebanon: Lebanese American University. 2012.

Rehia Dkk, Pemberdayan perempuan melalui media sosial. Simbolika. 2013. Kendal, Lory. Pengertian dan identitas dalam'cyberspace" performas gender, ras dan kelas. USA: california University 